\title{
Management of Vipadika through Ayurveda
}

\section{Case Report}

\section{Sneha Bhimrao Chandankar ${ }^{1 *}$, Vaishali Kuchewar ${ }^{2}$}

\author{
1. PG Scholar, 2. Professor \\ Department of Kayachikitsa, Mahatma Gandhi Ayurveda College, Hospital \& Research centre, \\ Salod(H), Wardha, Maharashtra.
}

\begin{abstract}
Vipadika,is one of the types of the Kshudrakushtha. There is involvement of Vata-Kaphadosha predominantly. It is characterized by PaniPadasphutna (fissure in palms and soles) and Tivravedana (severe local pain).Vipadika can be correlated with Palmo plantar psoriasis due to its similarity in clinical features. It is found in 3-4 \% of all psoriasis cases. Here is a case of chronic vipadika. She came to kayachikitsa OPD on 02/03/2017. She had history of consumption of continous medication since one year from modern medicine and homoeopathy. After clinical examination ,she was admitted in MGAMCH \& RC for 7 days and was treated with Yoga basti, oral medications and external applications. After discharge, she had prescribed medicines for oral and external application for 30 days. There was complete relief in fissure and pain and she has no recurrence upto the month of January 2019.
\end{abstract}

Keywords: Vipadika, Kshudrakushtha, Palmo-planter Psoriasis.

\section{Introduction}

Vipadika is one of the types of the Kushudrakushtha (dermatological disorder). It is included in Kshudrakushtha with VataKaphadosha involvement(1)and it is characterized by Pani-Padasphutan (fissure in palms and soles) and Tivravedana(severe pain) by AcharyaCharak(2)

Acharya Vagbhat has stated the same as described by Acharya Charaka but mentioned one feature of red patches over palm and sole. Vipadika can be correlated with Palmo plantar psoriasis which is a long lasting autoimmune disease characterized by red, itchy, scaly patches of the palms and soles, there are multiple painful fissures and bleeding also. It is found in 3-4 of all psoriasis cases. It's WHO prevalence is 0.44 $2.88 \%(3)$

In Modern medical science, it is commonly treated with PUVA, corticosteroids and immunemodulators, but the recurrence is common. This case is a chronic in nature and treated by multiple modalities, so it was a challenge for us to treat it completely.

*Corresponding Author:

\section{Sneha Bhimrao Chandankar}

PG Scholar, Department of Kayachikitsa,

Mahatma Gandhi Ayurveda College, Hospital \& Research centre,

Salod(H), Wardha, Maharashtra.

Email id: chandankar.sneha@gmail.com

\section{Case report}

A 54 year female patient came to kayachikitsa OPD (OPD NO - 1703020058) of Mahatma Gandhi Ayurveda Medical hospital, salod $(H)$, wardha on $02 / 03 / 2017$ with the complaints of cracks on both palms and soles with burning sensation and mild pain since 1 year. She has taken treatment of modern medicine and homeopathy and was getting temporary relief, due to recurrence of the symptoms, she approach here for further treatment. On examination, multiple deep fissures were present on both palms and soles with local tenderness. According to the clinical features, the patient was diagnosed as a case of vipadika. Clinical features indicated predominance of vata and kapha dosha. The treatment plan was a per the Table no 1 .

\section{Observation and results}

Following were the observation after completion of treatment

Table no. 2 - Clinical features : Before \& after treatment

\begin{tabular}{|c|c|c|c|}
\hline Sr no. & $\begin{array}{c}\text { Clinical } \\
\text { features }\end{array}$ & $\begin{array}{c}\text { Before } \\
\text { treatment }\end{array}$ & $\begin{array}{c}\text { After } \\
\text { treatment }\end{array}$ \\
\hline 1 & Scaling of skin & ++ & No scales \\
\hline 2 & Fissure & +++ & No fissure \\
\hline 3 & Pain & ++ & No pain \\
\hline
\end{tabular}

After near about one month of treatment, she had no recurrence till the month of January 2019. 
Table No. 1: Showing the treatment plan

\begin{tabular}{|c|c|c|c|c|}
\hline Sr no & $\begin{array}{l}\text { Type of } \\
\text { treatment }\end{array}$ & Name of drug & Dose and Anupana & Duration \\
\hline \multicolumn{5}{|c|}{ On admission treatment } \\
\hline \multirow[t]{2}{*}{1} & \multirow{2}{*}{$\begin{array}{l}\text { Yoga basti } \\
\text { (Medication } \\
\text { through } \\
\text { anal route ) }\end{array}$} & $\begin{array}{l}\text { Four Matra basti with } \\
\text { manjishthadi tail }\end{array}$ & \multirow{2}{*}{$\begin{array}{l}50 \mathrm{ml} \\
500 \mathrm{ml}\end{array}$} & \multirow[t]{2}{*}{7 days } \\
\hline & & $\begin{array}{l}\text { Three Niruha basti with } \\
\text { manjisthachurna }+ \\
\text { neemchurna }+ \text { sarivachurna } \\
+ \text { tiltail }+ \text { Madhu }+ \\
\text { Saindhav }\end{array}$ & & \\
\hline \multirow[t]{2}{*}{2} & \multirow[t]{2}{*}{$\begin{array}{l}\text { Oral } \\
\text { medications }\end{array}$} & Mahatiktaghruta & $\begin{array}{l}10 \mathrm{ml} \text { in the morning on empty } \\
\text { stomach with luke warm water }\end{array}$ & \multirow[t]{2}{*}{7 days } \\
\hline & & Sarivadyasava & $\begin{array}{l}20 \mathrm{ml} \text { twice a day after meal with equal } \\
\text { water }\end{array}$ & \\
\hline \multirow[t]{2}{*}{3} & \multirow[t]{2}{*}{$\begin{array}{l}\text { External } \\
\text { application }\end{array}$} & $\begin{array}{l}\text { Triphalakwath }+ \\
\text { neempatrakwath }\end{array}$ & Dhavan of both palms \& soles & \multirow[t]{2}{*}{7 days } \\
\hline & & $\begin{array}{l}\text { Shatdhautaghruta }+ \text { Cutfar } \\
\text { ointment }\end{array}$ & For local application twice a day & \\
\hline \multirow{2}{*}{\multicolumn{5}{|c|}{$\begin{array}{l}\text { Procedure of yoga basti- On first day, matra basti with manjishthadi tail was given after meal ,on next } \\
\text { day niruhabasti with above ingredients was given before meal. Matra and niruhabasti was given on } \\
\text { alternateday, total four matra and three niruhabasti were given for seven days. Above oral and external } \\
\text { medication were also advised during yoga basti. } \\
\text { On discharge treatment }\end{array}$}} \\
\hline & & & & \\
\hline \multirow[t]{4}{*}{4} & \multirow[t]{4}{*}{$\begin{array}{l}\text { Oral } \\
\text { medication }\end{array}$} & Kaishorguggul & $\begin{array}{l}500 \mathrm{mg} \text { twice a day with water after } \\
\text { meal }\end{array}$ & \multirow[t]{4}{*}{15 days } \\
\hline & & Sarivadyasava & $\begin{array}{l}20 \mathrm{ml} \text { twice a day with equal water } \\
\text { after meal }\end{array}$ & \\
\hline & & Tab. Nishamalaki & 1 tab in the morning with water & \\
\hline & & Yashadbhasma & $250 \mathrm{mg}$ twice a day with milk & \\
\hline 5 & $\begin{array}{l}\text { External } \\
\text { application }\end{array}$ & $\begin{array}{l}\text { Cutfar ointment } \\
\text { (jatyadi tail }+ \\
\text { vipadikaharamalam) }+ \\
\text { karanj tail }\end{array}$ & For local application & 15days \\
\hline \multicolumn{5}{|c|}{ After $15^{\text {th }}$ day of follow up treatment } \\
\hline 6 & $\begin{array}{l}\text { Oral } \\
\text { medication }\end{array}$ & Sarivadyasava & $\begin{array}{l}20 \mathrm{ml} \text { twice a day with equal water } \\
\text { after meal }\end{array}$ & 15 days \\
\hline 7 & $\begin{array}{l}\text { External } \\
\text { application }\end{array}$ & $\begin{array}{l}\text { Cutfar ointment }+ \text { karanj } \\
\text { tail }\end{array}$ & For local application & 15 days \\
\hline
\end{tabular}

\begin{tabular}{|c|c|c|c|}
\hline \multicolumn{2}{|c|}{ On the day of admission } & \multicolumn{2}{c|}{ On 22 ${ }^{\text {nd }}$ day of treatment } \\
\hline Figure no.1 & Figure no.2 & Figure no.3 & Figure no.4 \\
\hline & & & \\
\hline
\end{tabular}




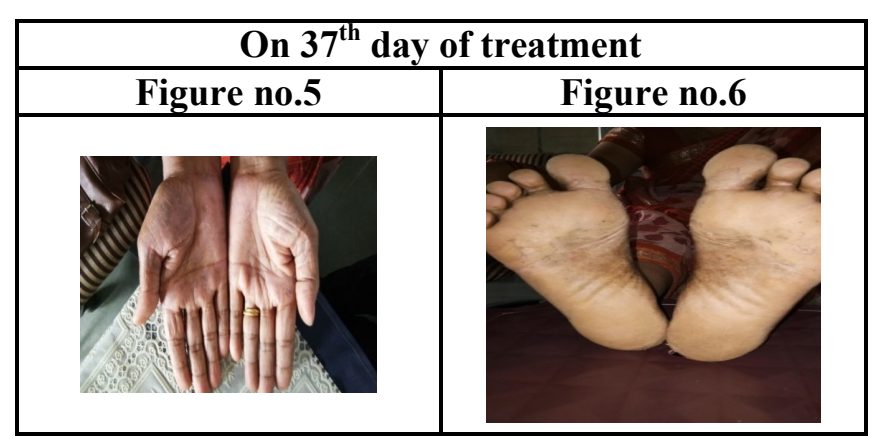

\section{Discussion}

Patient had fissures on her palms and soles and itching due to vitiation of vata and kapha respectively. The treatment was given in accordance with vitiation of these doshas. She was treated with yoga basti because basti is described as main treatment in vitiation of vata.

In matra and niruhabasti, manjishtha was specifically used because Manjishtha(rubiacordifolia) is described under varnya gana. It is having tikta, kashaya, madhura and ushna guna due to which it act as a vataghna and kaphaghna.

According to karma, it is shothahara, vranropak as well kushthaghna. Tikta and kashaya rasa of manjishtha pacifies rakta-mamsagata kleda .(4)

Neem and sarivachurna was also used because neem is raktashuddhikara and sariva has vatashamak and raktaprasadak property. (5)

Sarivadyasava is described as raktaPrasadak. It is working as a blood purifier and commonly used in various skin disorders. It cures diseases caused by vitiated raktadhatu(6)

Mahatiktaghruta is described in Vagbhat under the Kushtha chikitsaadhyay in which he has described it's effectiveness in kushtha ,visarpa, shvitra ,vyanga, vidradhi , kandu.(7)

Kaishor guggul is specifically indicated in vatarakta, vrana, and kushtha. In one study, they found it's antiallergic, antibacterial and blood purifying properties.(9)

Nishamalaki containts Amalaki (phyllanthusemblica) and Haridra(terminaliachebula). It works as an anti inflammatory \& anti allergic. It is also an anti oxidant property.(10)

Triphala and neem kwath was used for dhawan (cleaning) because of its vranashodhak, vranaropaka, kledashoshak and kandughna properties.(8)

Yashad Bhasma contains zinc which is known to promote healing (11)

Cutfar ointment mainly contains jatyadi tail was used for local application because jati has kushthaghna, vranashodhak, and vranaropak action(12).

Shatadhautaghruta is indicated in visarpa, kushtha and kandu.(13)

Karanjtail was used because of its kandughna and kushthaghna properties. It is Kaphaghna and Vataghna due to its tikta, katurasa and ushnavirya. It is also having jantughna, vranaropan and vedanasthapan (pain reliever) properties.(14)(15)

\section{Conclusion}

From this study it can be concluded that Vipadika (palmo-plantar psoriasis) can be successfully treated with appropriate Ayurvedic medication.

\section{References}

1. Yadavji T. Charak Samhita, Reprinted 2013, Chaukhamba Surbharti Prakasan, Varanasi, Chikitsha chap. 7/22, 7/13, 29, 451p .

2. Shastri K. Bhaishajya Ratnavali, 19th edition, Choukhamba prakashan, 2008, Chapter. 54, 905p.

3. Jakhotiya Y. Kuchewar V. Ayurvedic management of Palmoplanter Psoriasis: A Case Study, J of Ayurveda and Hol Med (JAHM).2017;5(2):59-64p

4. Pandey G, Davyaguna vigyan, vol II ,Choukhamba Krishnadas academy :reprint, 2004, 500p

5. Pandey G, Davyaguna vigyan, vol II ,Choukhamba Krishnadas academy :reprint, 2004, 500p

6. Kuchewar V. Management of chronic psoriasis through Ayurved. Joinsysmed 2017, vol 5( ),111$115 p$

7. Tripathi B, Ashtang hriday ed.2014 Choukhamba sanskrut pratishthan. Chapter 19th, 783p

8. Lather A. Gupta V. Bansal P. Sahu M. An ayurvedic polyherbal formulations of kaishor guggula - a review 2011Journal of IJPBA.28.jan.2018,2(1),497$503 p$

9. Kuchewar V. Management of chronic psoriasis through Ayurved. Joinsysmed 2017, vol 5( ),111$115 \mathrm{p}$

10. Lal K. Susruta Samhita, An English translation of the Sushruta samhita, based on original Sanskrit text. Vol. 2;1907;344p.

11. Kuchewar V. Management of chronic psoriasis through Ayurved. Joinsysmed 2017, vol 5( ),111$115 \mathrm{p}$

12. Jakhotiya Y. Kuchewar V. Ayurvedic management of Palmoplanter Psoriasis: A Case Study, J of Ayurveda and Hol Med (JAHM).2017;5(2):59-64p

13. Di Pompo G, Poli F,Mandrone M, Lorenzi B, Roncuzzi L, Baldini N, Granchi D.J, Comparative "in vitro" evaluation of the antiresorptive activity residing in four Ayurvedic medicinal plants ethnopharmacol . 2014 Jun 11;154(2):462-7p

14. Rao P , Bhaishajya kalpana vigyan , Edition:2008 Chaukhambha Sanskrit sansthan ,13/44, 328p.

15. Jakhotiya Y. Kuchewar V. Ayurvedic management of Palmoplanter Psoriasis: A Case Study, $J$ of Ayurveda and Hol Med (JAHM).2017;5(2):59-64p. 